\title{
Hepatitis B virus infected health care workers in the Netherlands, 2000-2008
}

\author{
T. J. Daha • M. A. J. Bilkert-Mooiman • C. Ballemans • \\ G. Frijstein • J. N. Keeman • R. A. de Man • \\ J. E. van Steenbergen • G. Weers-Pothoff • H. L. Zaaijer
}

Received: 19 January 2009 / Accepted: 27 March 2009/Published online: 7 April 2009

(C) The Author(s) 2009. This article is published with open access at Springerlink.com

\begin{abstract}
In response to the confirmed transmission of hepatitis B virus (HBV) from a surgeon to several patients in the Netherlands, a 'Committee for Prevention of Iatrogenic Hepatitis B' was established in 2000. During the years 20002008, the committee reviewed 99 cases of HBV-infected health care workers. Fifty of them were found to perform exposure prone procedures (EPPs). Because of high levels of HBV DNA ( $>100,000$ copies $/ \mathrm{ml})$, a ban on performing EPPs was applied in 11/50 cases; 25/50 low-viremic health care workers were allowed to continue EPPs while their HBV load was being monitored; and 14/50 cases had stopped working or changed profession. In five restricted workers who started oral antiviral treatment, HBV replication was persistently suppressed, enabling the ban on EPPs to be lifted. Throughout the
\end{abstract}

European Union different levels of HBV viremia have been chosen, above which health care workers are not allowed to perform EPPs. It remains unknown how this affects the safety of patients. Application in the Netherlands of a European or a British guideline would have, respectively, doubled or tripled the number of restricted health care workers.

\section{Introduction}

In 1999, a Dutch surgeon transmitted hepatitis B virus (HBV) to at least eight patients and possibly to a total of 28 patients [1]. Literature shows that this form of transmission is not unique, numerous cases of HBV transmission from
T. J. Daha

Office of the Infection Prevention Working Party,

Leiden University Medical Centre,

Leiden, The Netherlands

M. A. J. Bilkert-Mooiman

Dutch Health Care Inspectorate,

Zwolle, The Netherlands

C. Ballemans

Utrecht Network for Infection Control,

Utrecht, The Netherlands

G. Frijstein

Occupational Health and Safety Department,

Academic Medical Centre,

Amsterdam, The Netherlands

J. N. Keeman

Association of Surgeons in the Netherlands,

Amsterdam, The Netherlands

\section{R. A. de Man}

Department of Gastroenterology and Hepatology,

Erasmus Medical Centre,

Rotterdam, The Netherlands

J. E. van Steenbergen

Center for Infectious Diseases Control,

National Institute for Public Health and the Environment (RIVM),

Bilthoven, The Netherlands

G. Weers-Pothoff

Department of Medical Microbiology, Jeroen Bosch Hospital,

Den Bosch, The Netherlands

H. L. Zaaijer ( $\bowtie)$

Sanquin Research and Landsteiner Laboratory,

Academic Medical Centre, University of Amsterdam,

AMC Room K1-121, P.O. Box 22660, 1100DD Amsterdam,

The Netherlands

e-mail: h.1.zaaijer@amc.uva.nl 
health care workers to patients have been reported, as reviewed by Mele and Gunson [2, 3]. In 2000, the Dutch Health Care Inspectorate established the 'Commissie Preventie Iatrogene Hepatitis B' (Committee for Prevention of Iatrogenic Hepatitis B; hereinafter referred to as the Committee). The Committee was asked (1) to review all HBV-infected health care workers in the Netherlands who potentially perform exposure prone procedures (EPPs) and to advise them on how to prevent transmission; and (2) to develop a national guideline for the prevention of transmission of HBV from health care workers to patients. The guideline on prevention of iatrogenic hepatitis B was published in June 2002 and was subsequently endorsed by the Dutch Health Council [4]. In 2003 a European consensus guideline became available [3]. Since 2003 national guidelines for the management of infected health care workers have been instituted in several countries, as reviewed during a meeting of the Viral Hepatitis Prevention Board in 2005 [5].

To prevent iatrogenic transmission of HBV, the Dutch guideline states that the HBV status of all medical personnel performing EPPs must be known. The definition of EPPs was adopted from a report of the UK Health Advisory Group [6]. This report defines EPPs as follows: "Exposure prone procedures (EPPs) are those where there is a risk that injury to the worker may result in exposure of the patient's open tissues to the blood of the worker. These procedures include those where the worker's gloved hands may be in contact with sharp instruments, needle tips or sharp tissues (spicules of bone or teeth) inside a patient's open body cavity, wound or confined anatomical space where the hands or fingertips may not be completely visible at all times."

In all but one case of reported HBV transmission to a patient, the level of HBV viremia in the health care worker was higher than 100,000 copies $/ \mathrm{ml}[3,7]$. Balancing the risk of HBV transmission and the loss of medical specialists, the HBV DNA threshold level above which the Dutch guideline prohibits EPPs was chosen to be 100,000 copies/ml. In an HBV-infected person who performs EPPS, it has to be demonstrated twice yearly that the HBV viremia remains below this threshold. Antiviral maintenance therapy using HBV polymerase inhibitors may successfully suppress the level of HBV DNA below 100,000 copies/ml. In this situation the level of HBV viremia in the health care worker must be monitored every three months.

To ensure proper management of HBV-infected health care workers, and to help decide whether a procedure is exposure prone or not, in the Netherlands every HBV-infected health care worker potentially performing EPPs must be reported to the Committee for evaluation and advice. To facilitate reporting, a local official may report an anonymous case. This article describes the number and nature of HBV- infected health care workers in the Netherlands as submitted to the Committee in the years 2000-2008.

\section{Methods}

HBV-infected health care workers

The Committee for Prevention of Iatrogenic Hepatitis B considered the nature of the professional activities and reviewed the HBV-related laboratory test results of all HBV-infected health care workers that were submitted. The confidential database containing the reviews and test results of the submitted cases was accessed only by members of the Committee, thus guaranteeing the privacy of the persons involved. All HBV-infected health care workers were placed into one of the following three categories: performing EPPs, not performing EPPs, or potentially performing EPPS in the future. The latter category applied to medical students who do not yet perform invasive procedures. Although medical interns in the Netherlands in general do not perform EPPs, medical interns were categorized as 'performing EPPs', because they unexpectedly may encounter exposure prone situations.

For this report, all HBV DNA test results expressed in international units were converted from $\mathrm{IU} / \mathrm{ml}$ to copies $/ \mathrm{ml}$, assuming that $1 \mathrm{IU}$ equals 5.8 copies of HBV DNA.

\section{Results}

Number and nature of HBV-infected health care workers

From 2000-2008, 99 cases of HBV-infected health care workers were submitted to the Committee for reviewing and advice. Fifty of the $99 \mathrm{HBV}$-infected health care workers performed EPPs (see Table 1). Seven of 99 were medical students who may perform EPPs in the future, and 42 were categorized as not performing EPPs, which included general practitioners, a nuclear physician, a pulmonologist, a geriatric doctor, nurses, technicians, researchers, drivers, janitors, etc. The 50 EPP performing persons included 20 medical specialists (of which seven were still in training), nine dentists (four in training), 11 medical interns, three midwives, two operating room assistants, two dentistry assistants, two dental hygienists, and one surgical intensive care nurse.

Eleven of the 50 EPP performing persons had a viral load above the Dutch threshold level (100,000 HBV DNA copies $/ \mathrm{ml}$ ); hence they were no longer allowed to perform EPPs. Twenty-five persons had a HBV DNA load below the threshold value, enabling them to perform EPPs provided that their HBV DNA load is monitored. The duration of 
Table 1 Number and nature of HBV-infected health care workers as submitted to and reviewed by the Dutch Committee for prevention of iatrogenic hepatitis B
$H B V$ hepatitis B virus, $E P P$ exposure prone procedure

\begin{tabular}{lllll}
\hline Year & \multicolumn{2}{l}{ Personnel } & & \\
\cline { 2 - 5 } & Performing EPPs & $\begin{array}{l}\text { Potentially performing } \\
\text { EPPs in future }\end{array}$ & Not performing EPPs & Total \\
\hline 2000 & 12 & 0 & 15 & 27 \\
2001 & 9 & 0 & 8 & 17 \\
2002 & 4 & 0 & 5 & 9 \\
2003 & 7 & 2 & 8 & 17 \\
2004 & 8 & 2 & 4 & 14 \\
2005 & 3 & 0 & 2 & 5 \\
2006 & 2 & 3 & 0 & 5 \\
2007 & 3 & 0 & 0 & 3 \\
2008 & 2 & 0 & 0 & 2 \\
Total & 50 & 7 & 42 & 99 \\
\hline
\end{tabular}

monitoring in these persons ranged from 0 to 106 months (median 54 months). Monitoring of HBV DNA did not take place in 14/50 persons because they stopped working, moved abroad, died, or changed profession. In the 25 persons undergoing monitoring of HBV DNA, the highest level of HBV DNA encountered during follow-up was as follows: below 1,000 copies/ml in $4 / 25$ persons, between 1000 and 10,000 copies/ml in $10 / 25$ persons, and between 10,000 and 100,000 copies/ml in $11 / 25$ persons. Table 2 shows the number of restricted persons if other HBV DNA threshold levels would have been applied.

According to the Dutch guideline, HBV-infected persons may perform EPPs again if antiviral therapy forces the HBV load below 100,000 copies/ml, provided that threemonthly monitoring of HBV DNA takes place. In five of the 11 restricted cases the ban could be lifted because of successful antiviral therapy. In one of the 11 restricted cases the HBV DNA level initially was low. During follow-up the level of HBV DNA increased, exceeding the threshold value and necessitating a ban on EPPs.

One of the four dentistry students had a high HBV load and initially was prohibited to carry out EPPs, which meant that the training had to be postponed. Later on, successful antiviral treatment enabled continuation of the study. Nevertheless, the dentistry students, medical students, medical interns and medical-specialists-in-training were advised to consider a non-EPP profession, because the possibility of them developing a high viral load in the future could not be excluded.

\section{Discussion}

Over a period of nine years, from 2000 to 2008, $99 \mathrm{HBV}$ infected health care workers were reported to the Committee for prevention of iatrogenic hepatitis B in the Netherlands. A ban on performing EPPs had to be imposed in eleven cases. The Committee continues to receive requests for advice on HBV-infected personnel, but the number of submitted health care workers decreased after 2004 (see Table 1). This can be attributed to the fact that most 'prevalent' HBV-infected persons have been detected and only new 'incident' cases are to be reviewed. In addition, local officials have learned to determine which health care workers certainly do not perform EPPs and thus are not to be submitted for review by the Committee.

It is unknown how many HBV-infected, EPP-performing health care workers went unreported. To investigate whether the safety of patients was sufficiently safeguarded with regard to the prevention of hepatitis $\mathrm{B}$, and to enforce reporting, in 2002 and 2003 the Dutch Health Care Inspectorate sent a standardised questionnaire on the local HBV vaccination status and testing policy to all hospitals, independent treatment centres and private clinics in the Netherlands. Responses to the questionnaire showed that $75 \%$ of the institutions lacked an effective HBV prevention policy. Subsequently, a representative of the Dutch Health Care Inspectorate (author B-M) visited selected hospitals, checking local vaccination and control procedures and explaining the liability if the Guideline appeared not to be
Table 2 Number of HBVinfected health care workers excluded from exposure prone procedures according to various HBV DNA threshold levels

$H B V$ hepatitis B virus
HBV DNA threshold level (copies/ml)

Percentage of restricted personnel

\begin{tabular}{ll}
\hline 100,000 & $31 \%(11 / 36)$ \\
10,000 & $61 \%(22 / 36)$ \\
1000 & $89 \%(32 / 36)$ \\
\hline
\end{tabular}


implemented. By March 2004, more than $80 \%$ of the hospitals had their prevention policies in order. Since 2005, all hospitals, independent treatment centres, and private clinics known to the Dutch Health Care Inspectorate adhere to the Dutch guideline on prevention of iatrogenic hepatitis B. In conclusion, the exact residual risk probably is low, but remains unknown. The level of HBV viremia in the health care workers who continued to perform EPPs while being monitored varied considerably from person to person. Threshold levels, above which EPPs are prohibited, vary from country to country [5]. If the European consensus threshold level (10,000 HBV DNA copies/ml) would have been applied in the Netherlands, the number of restricted workers would have doubled. Application of the British threshold level $(1000$ copies $/ \mathrm{ml})$ would have nearly tripled the number of restrictions (see Table 2). Unfortunately, it remains unknown how these different threshold values affect the safety of patients, as no follow-up takes place of patients undergoing EPPs by HBV-infected personnel.

During the last decade inhibitors of HBV polymerase gradually became available for treatment of chronic HBV infection. Lamivudine and adefovir were approved by the Federal Drug Administration in 1998 and 2002, and received marketing authorization for the European Union in 1999 and 2003. Unfortunately, these early HBV inhibitors frequently cause the emergence of drug-resistant HBV variants $[8,9]$. Hence, in the first years of the Committee's existence, longterm medically maintained suppression of HBV replication did not seem a solution for highly viremic, EPP performing personnel. More recent HBV inhibitors like entecavir and tenofovir display a much more favourable resistance profile $[10,11]$. Buster et al. have shown that prolonged antiviral therapy for HBV-infected health care workers is a viable option instead of work restriction, provided that the level of HBV DNA is monitored regularly [12]. Indeed in five cases the ban on EPPs could be lifted, because of successful suppression of HBV. More cases are expected to follow. Nevertheless, it remains questionable whether highly viremic dentistry students and surgeons in training should rely on long-term antiviral medication. The future will tell whether a switch to a non-exposure prone profession would have been wiser.

Acknowledgements The present members of the 'Committee for prevention of iatrogenic hepatitis $\mathrm{B}$ ' in the Netherlands thank two former members, Prof. Dr. J. van der Noordaa and Prof. Dr. S.W. Schalm, for their work and guidance.

Open Access This article is distributed under the terms of the Creative Commons Attribution Noncommercial License which permits any noncommercial use, distribution, and reproduction in any medium, provided the original author(s) and source are credited.

\section{References}

1. Spijkerman IJ, van Doorn LJ, Janssen MH et al (2002) Transmission of hepatitis B virus from a surgeon to his patients during high-risk and low-risk surgical procedures during 4 years. Infect Control Hosp Epidemiol 23:306-312. doi: $10.1086 / 502056$

2. Mele A, Ippolito G, Craxi A et al (2001) Risk management of HBsAg or anti-HCV positive healthcare workers in hospital. Dig Liver Dis 33:795-802. doi:10.1016/S1590-8658(01)80698-8

3. Gunson RN, Shouval D, Roggendorf M et al (2003) Hepatitis B virus $(\mathrm{HBV})$ and hepatitis $\mathrm{C}$ virus $(\mathrm{HCV})$ infections in health care workers (HCWs): guidelines for prevention of transmission of HBV and HCV from HCW to patients. J Clin Virol 27:213-230. doi:10.1016/S1386-6532(03)00087-8

4. Commissie voor preventie van iatrogene hepatitis B (2007) Landelijke richtlijn preventie iatrogene hepatitis B - second edition. RIVM - Centrum Infectieziektenbestrijding, Bilthoven, The Netherlands

5. The Viral Hepatitis Prevention Board (2005) Differing guidelines toward the infected healthcare worker. Viral Hepat 14:14

6. UK Health Advisory Group (1998) HIV infected health care workers: guidance on management and patient notification. Department of Health, United Kingdom

7. Corden S, Ballard AL, Ijaz S et al (2003) HBV DNA levels and transmission of hepatitis B by health care workers. J Clin Virol 27:52-58. doi:10.1016/S1386-6532(02)00127-0

8. Liaw YF, Sung JJ, Chow WC et al.; Lamivudine Multicentre Study Group (2004) Lamivudine for patients with chronic hepatitis B and advanced liver disease. N Engl J Med 351:15211531. doi:10.1056/NEJMoa033364

9. Fung SK, Chae HB, Fontana RJ et al (2006) Virologic response and resistance to adefovir in patients with chronic hepatitis B. J Hepatol 44:283-290. doi:10.1016/j.jhep.2005.10.018

10. Dimou E, Papadimitropoulos V, Hadziyannis SJ (2007) The role of entecavir in the treatment of chronic hepatitis B. Ther Clin Risk Manage 3:1077-1086

11. Reijnders JGP, Janssen HLA (2008) Potency of tenofovir in chronic hepatitis B: Mono or combination therapy? J Hepatol 48:383-386. doi:10.1016/j.jhep.2007.12.006

12. Buster EH, van der Eijk AA, de Man RA et al (2007) Prolonged antiviral therapy for hepatitis B virus-infected health care workers: a feasible option to prevent work restriction without jeopardizing patient safety. J Viral Hepat 14:350-354. doi:10.1111/j.13652893.2006.00809.x 